\title{
Books on \\ Japanese Business History \\ Published in 2008
}

Аво, Kunihiko, Chūbu no sangyō: kōzō-henka to kigyōka-tachi [Industry in the Chubu Region: Structural Change and the Entrepreneurs] (Osaka, Seibundo shuppan)

Enoki, Kazue, Kindai seishigyō no koyō to Keiei [Employment and Management in the Early Modern Spinning Industry] (Tokyo, Yoshikawa kōbunkan)

FujII, Takashi, Yanagida Kunio: Sangyō kumiai to Tōno monogatari no aida [Yanagida Kunio: Between "Industrial Unions" and "Tales of Tono"] (Tokyo, Nihon keizai hyōronsha)

Fujıno, Shōzaburō, Nihon no Keizai seichō to keiki junkan [Japan's Economic Growth and the Economic Cycle] (Tokyo, Keisō shobō)

Hori, Kazuo, ed., Higashi-Ajia shihon shugishi ron 2: Kōzō to tokushitsu [The History of Capitalism in East Asia, vol.2: Structure and Characteristics] (Kyoto, Minerva shobō)

HuAng, Rong-guang, Kindai nicchū bōeki seiritsu shiron [The Early Modern Development of Japan-China Trade] (Tokyo, Hikaku bunka kenkyūjo)

This book researches Kogyo Shokai, the best-capitalized trading company in the first half of the Meiji era. Kogyo Shokai was founded in 1876 for the primary purpose of trading with China. The collection and careful reading of a large number of company-related documents allow this book to shed light on many aspects of the company not covered by 
earlier research. Supported by the Satsuma faction's human networks, the company was founded as an integral part of the Meiji government's trade policy. This book portrays the process of the firm's evolution from a highly successful exporter of konbu seaweed to China to its dissolution 14 years later against the background of changing government policy.

Iкео, Aiko, Akamatsu Kaname: Waga taikei wo norikoeteyuke [Akamatsu Kaname: Surpass my System if You Can] (Tokyo, Nihon keizai hyōronsha)

INOKI, Takenori, Senkanki Nihon no shakai shüdan to network: Democracy to chūkan dantai [Social Groupings and Networks in Wartime Japan: Democracy and Intermediate Organizations] (Tokyo, NTT shuppan)

IsHI, Hiromitsu, Gendai zeisei kaikaku-shi: Shūsen kara bubble hōkai made [The History of Postwar Tax Reform: From War's End to the Implosion of the Bubble Economy] (Tokyo, Tōyō keizai shinpōsha)

Ітон, Mamiko, Meiji Nippon to bankoku hakurankai [Meiji Japan and the World Exposition] (Tokyo, Yoshikawa kōbunkan)

IwaI, Yoshiya, Take no keizaishi: Nishi-nihon ni okeru take sangyō no hensen [An Economic History of Bamboo: Western Japan and the Vicissitudes of the Bamboo Industry] (Kyoto, Shibunkaku shuppan)

Kамікuво, Satoshi, Shimomura Osamu: Nihon keizaigaku no jissensha [Shimomura Osamu: Practicioner of "Japanese Economics"] (Tokyo, Nihon keizai hyōronsha)

Kensō, Teiji, Shibusawa Eiichi: Dōtoku to keizai no aida [Shibusawa Eiichi: Between Ethics and Economics] (Tokyo, Nihon keizai hyōronsha)

Kikkawa, Takeo and Shimada, Masakazu, eds., Shinka no keieishi: Hito to soshiki no flexibility [The Evolution of Business History: The Flexibility of Men and Organizations] (Tokyo, Yūhikaku)

Kobayashi, Hideo, Shibata, Yoshimasa and Yoshida Sennosuke, eds., Sengo ajia ni okeru Nihonjin dantai: Hikiage kara kigyō shinshutsu made [Japanese Associations in Postwar Asia: From Repatriation to Corporate Direct Investment] (Tokyo, Yumani shobō)

Kudō, Akira and Tajima, Nobuo, eds., Nichidoku kankeishi 1890-1945 Vol.1. Sōsetsu/Higashi-ajia ni okeru kaikō [A History of Japanese- 
German Relations, 1890-1945 Vol. 1 General Remarks: Chance Encounters in East Asia] (Tokyo, Tokyo U.P)

Kudō, Akira and TAJima, Nobuo, eds., Nichidoku kankeishi 1890-1945 Vol.2 Süjiku keisei no tagenteki rikigaku [A History of JapaneseGerman Relations, 1890-1945 Vol. 2 The Multifaceted Dynamics of Forming the Axis] (Tokyo, Tokyo U.P)

Kudō, Akira and TAJima, Nobuo, eds., Nichidoku kankeishi 1890-1945 Vol.3 Taisei hendō no shakaiteki shōgeki [A History of JapaneseGerman Relations, 1890-1945 Vol. 3 The Social Impact of the Changing Order] (Tokyo, Tokyo U.P)

KusuI, Toshirō, Ōtuka Hisao ron [Thoughts about Otsuka Hisao] (Tokyo, Nihon keizai hyōronsha)

Maeda, Hiroko, Suisen toire no sangyō-shi: 20 seiki Nihon no miezaru innovation [The Industrial History of the Flush Toilet: Hidden Innovation in 20th Century Japan] (Nagoya, Nagoya U.P)

This book examines the process by which the flush toilet, that most familiar of home appliances, was manufactured and widely diffused during the period from the beginning of the $20^{\text {th }}$ century to the 1970 's. An analysis of this process reveals not only the development of the flush toilet manufacturing industry, which involved not only the simultaneous development of constituent parts such as the porcelain toilet bowl, metal valves and pipes fittings, etc, but also the development of a wide variety of related technologies including municipal water supply and waste water systems, construction techniques etc. The author also explores the relationship between the thought, behavior and productive activities of the firms, technical specialists and others involved in this process.

Matsumura, Takao and Yanagisawa, Asobu, eds., Mantetsu no chōsa to kenkyü: Sono shinwa to jitsuzō [A Research Study of the South Manchuria Railway Company: Myth and Reality] (Tokyo, Akashi shoten)

MiYaj, Hidetoshi, Kindai Nihon no tojiki-gyō: Sangyō hatten to seisan soshiki no fukusōsei [The Porcelain Industry in Early Modern Japan: Industrial Progress and the Stratification of Company Organization] (Nagoya, Nagoya U.P)

NaKamura, Muneyoshi, Gotō Fumio: Jinkaku no tōsei kara kokka 
shakai no tōsei e [Goto Fumio: From Controlling the Individual to Controlling Society] (Tokyo, Nihon keizai hyōronsha)

Nisso, Nichiro Keizai Koryūshi Shuppan Group, ed., Nisso Nichiro keizai koryū-shi: Roshia Business ni kaketa hitobito no monogatari [A History of Japan-Soviet and Japan-Russia Economic Exchange: Men Who Staked their Lives on the Russia Business] (Tokyo, Tōyō shoten)

Noguchi, Yukio, Sengo nihon keizaishi [An Economic History of Postwar Japan] (Tokyo, Shinchōsha)

OCHIAI, Kō, Ōkubo Toshimichi: Kokken no michi wa keizai kara [Okubo Toshimichi: The Road to National Sovereignty Begins with the Economy] (Tokyo, Nihon keizai hyōronsha)

Oıкawa, Yoshinobu, Kindai Nihon no shakai to kotsū Vol.3: Kindai nihon no tetsudō to shisō [Transportation and Society in Early Modern Japan, Vol. 3: Railroads and Thought in Early Modern Japan] (Tokyo, Nihon keizai hyōronsha)

Окаве, Makio, ed., Minami- manshū tetsudō gaisha no kenkyū [A Study of the South Manchuria Railway Company] (Tokyo, Nihon keizai hyōronsha)

Окамото, Makiko, Shokuminchi kanryō no seijishi: Chōsen - Taiwan sōtokufu to teikoku Nippon [A Political History of the Colonial Bureaucracy: The Colonial Government of Taiwan and Imperial Japan] (Tokyo, Sangensha)

ŌMORI, Kazuhiro, Morimura Ichizaemon: Tsushō rikkoku Nihon no ninaite [Morimura Ichizaemon: Pillar of the Japanese Trading State] (Tokyo, Nihon keizai hyōronsha)

This book is a critical biography of Morimura Ichizaemon, one of the first Japanese entrepreneurs to enter the American market. His Noritake porcelains have maintained a high reputation overseas until today. Morimura, a Christian, is well known for his voluntary, educational and patronage activities, but this invaluable book is the first to also give us a full portrait of his business dealings, including the primary business partners and companies he dealt with. The book stresses that Morimura sought to improve Japan's international competitiveness not only by establishing a reputation for product excellence backed by first-rate technology, but also by enhancing the societal reputation of the firm 
itself.

Sagara, Eisuke Sensei Taishokukinen Ronshū Kankōkai. ed., Tatara seitetsu - Iwami ginzan to chiiki shakai: Kinsei kindai no Chūgoku chihō [Tatara Ironmaking, the Iwami Silver Mine and Local Society: The Chugoku Region in the Early Modern Era] (Osaka, Seibundō shuppan)

SAitō, Osamu, Hikaku keizai hatten-ron: Rekishiteki approach [Comparative Economic Development Theory: A Historical Approach] (Tokyo, Iwanami shoten)

SAKAI, Ryōsuke, Zakoba uo-ichiba-shi: Ōsaka no seigyo ryūtsū $[A$ History of the Zakkoba Fish Market: Fresh Fish Distribution in Osaka] (Tokyo, Seizandō shoten)

Sнibata, Yoshimasa, Chūgoku senryōki Nikkei-kigyō no katsudō [Chronicles of Occupied China: Japanese Corporate Activities] (Tokyo, Nihon keizai hyōronsha)

Shimotani, Masahiro, Shinkō konzern to zaibatsu: Riron to rekishi [New Konzerns and the Zaibatsu: History and Theory] (Tokyo, Nihon keizai hyōronsha)

SHINOZAKI, Takao, Tōhata Seiichi no keizai shisō: Kyōdō kigyō/kigyōshal soshite chiiki [The Economic Thought of Tohata Seiichi: Joint Companies, Entrepreneurs and Local Society] (Tokyo, Nihon keizai hyōronsha)

SHioJ, Hiromi, ed., Higashi-Ajia yūi-sangyō no kyōsōryoku [The Competitive Strength of East Asia's Dominant Industries] (Kyoto, Minerva shobō)

Shiomi, Haruhito, eds., Nichibei kigyō no grobal kyōsō senryaku: New economy to ushinawareta jūnen no saikenshō [Global Competitive Strategies of Japanese and American Companies: Re-Examining the New Economy and the "Lost Decade"] (Nagoya, Nagoya U.P)

This book, building on the foundations laid by Shiomi Haruhito and Hori Ichiro in their co-edited book, Nichibei-kankei keieishi [An Economic History of Japan-U.S. Relations from the Era of Rapid Growth to the Present] (Nagoya U.P 1998), analyzes the competitive strategies of Japanese and American companies in the context of the subsequent acceleration of the globalization process, while evaluating 
the consequences of these strategies from an international relations management perspective. The contributors to this volume, all members of the Business History Society of Japan, are leaders in their respective fields. The main task of the book is to shed light on the question of what the so-called 'Lost Decade' of the 1990's meant to the companies of both countries. Covering the period from the Oil Shock to the present, this volume places especial emphasis on the period from 1985 to 2005. Industrial sectors examined include the information technology, automotive, steel, communications, finance, pharmaceutical, distribution and general trading sectors.

Shizuki, Manabu, Nihon no sangyō hatten: Kigyō bokkō to leading sangyō/chūshō kigyō [The Growth of Japanese Industry: The Sudden Rise of Corporations and Leading Companies/Small- and MediumSized Companies] (Tokyo, Sōseisha)

SukenARI, Yasushi, Jütaku no rekishi shakai-gaku: Nichijō seikatsu wo meguru keimō/dōin/sangyōka [A Socio-Historial Look at the "Home": The Education, Mobilization and Industrialization of Daily Life] (Tokyo, Shin'yōsha)

TAkeda, Haruhito, ed., Sengo fukkōki no kigyō kōdō: Tachihadakatta shōgai to sono kokufuku [Corporate Behavior in the Postwar Reconstruction Period: Overcoming Obstacles] (Tokyo, Yūhikaku)

TANI, Yahei, Kinsei Yoshino ringyō-shi [The Early Modern History of Yoshino Forestry] (Kyoto, Shibunkaku shuppan)

Terade, Michio, Yamada Moritarō: Marx shugisha no shirarezaru sekai [Yamada Moritarō: The Hidden World of a Marxist] (Tokyo, Nihon keizai hyōronsha)

Tokyo Nōdai, Еломото and Yoко Kenkyūkai, ed, Enomoto Takeaki to Yokoi Tokiyoshi: Tokyo nōdai futari no gakusō [Enomoto Takeaki and Yokoi Tokiyoshi: The Co-Founders of the Tokyo University of Agriculture] (Tokyo, Tokyo University of Agriculture Press)

Usami, Hideki, Kinsei Kyōto no kingin dashiire to shakai shūkan [Law, Social Customs and the Resolution of Monetary Disputes in Early Modern Kyoto] (Osaka, Seibundō shuppan)

Yamagata, Mariko, Tōjiki senbaisei to chuō shijō [The Monopolization of Pottery Sales by Feudal Fiefdoms and the Central Market] (Tokyo, Nihon keizai hyōronsha) 
Yoshinara, Kenji and Wada, Masaru, Nihon iryō-hoken seido-shi zōhokaiteiban [The History of Japan's Medical Insurance System: The Enlarged and Updated Edition] (Tokyo, Tōyō keizai shinpōsha)

Yu, Chen, Shibusawa Eiichi to giri shisō: Kindai higashi-Ajia no jitsugyō to kyōiku [Shibusawa Eiichi and the Philosophy of "Giri": Education and Industry in Early Modern East Asia] (Tokyo, Perikansha) 